\title{
Association of Comorbid with Developmental Quotient in Down Syndrome Children
}

\begin{abstract}
I Gusti Ayu Trisna Windiani*, Ni Made Dewi Aryati, I Gusti Agung Ngurah Sugitha Adnyana, Ni Luh Sukma Pratiwi Murti,
\end{abstract} Soetjiningsih Soetjiningsih

Department of Child Health, Faculty of Medicine, Udayana University, Denpasar, Indonesia

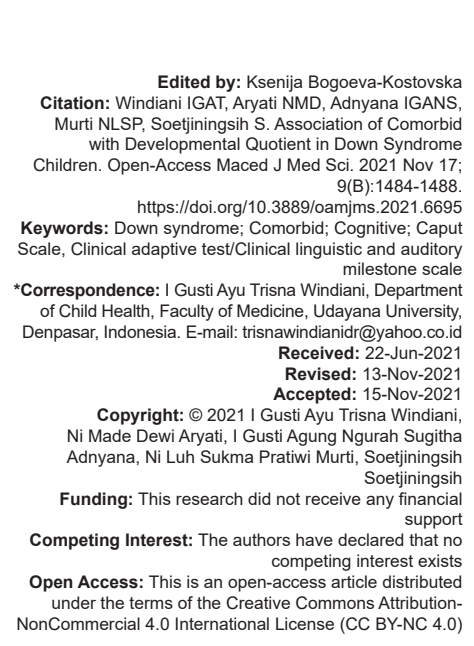

Introduction

Down syndrome (DS) is the most common genetic disorder found in children. Intellectual disability and other mental disorders can cause various health and developmental problems which are quite complex [1]. Management of DS in clinical practice is still limited to dealing with existing complaints. Comprehensive treatment that involves multidisciplinary science at every stage of a child's growth and development is needed to improve their quality of life in the future [1], [2], [3].

The incidence of DS in the United States is estimated 1 per 600-800 live births [3], while in Indonesia based on the results of the Basic Health Research (Riskesdas) in 2010, the cases of DS were $0.12 \%$ and increased in 2013 to $0.13 \%$, and 2018 into $0.21 \%$ [4], [5]. This figure corresponds to the average incidence of 1 per thousand children reported in many studies. Research in America reported that the prevalence of DS increased by $31 \%$ in births of mothers aged 35 years and over [6].
Children with DS tend to have various mental disorders and malformations due to developmental abnormalities of chromosome 21 in the form of trisomy 21, translocation, or mosaicism. This chromosomal abnormality decreases the neurons in the central nervous system, delayed myelination and an irregular cell cycle which, in turn, leads to increased production of protein precursors and neurotransmitter abnormalities. The phenotype varies but generally provides sufficient constitutional features for the experienced clinician to suspect DS [7].

Comorbidities often accompany children with SD such as congenital heart defects $50 \%$, hearing loss $75 \%$, otitis media $50-70 \%$, eye disorders $60 \%$ including cataracts $(15 \%)$ and severe refractive errors $(50 \%)$, obstructive sleep apnea $50-75 \%$, thyroid hormone disorders $15 \%$, gastrointestinal atresia $12 \%$, hip joint dislocation $6 \%$, and leukemia and Hirschsprung's disease < $1 \%$ [4], [6].

Children with DS show cognitive impairments in concentration, communication, memory, and the ability to carry out tasks [7]. Comorbidities that occur 
in DS children are often associated with the degree of development or growth. Research in Japan [8] showed that the speed of development of children with DS was slower than their peers who are not DS. This delay is associated with the number of comorbidities present in children with DS.

The degree of intellectual disability in DS children varies, ranging from mild intellectual disability (IQ: 50-70) to moderate (IQ: 35-49) and sometimes (rarely) severe intellectual disability (IQ: 20-34) [8]. Caput Scale/Clinical Adaptive Test/Clinical Linguistic and Auditory Milestone Scale (CAT-CLAMS) is one of the developmental assessment instruments that can be used to screen for cognitive disorders (language and visual-motor) in all children including children with DS [9]. Development quotient (DQ) is a score in the CAT-CLAMS questionnaire that will describe the proportion development in the child [9].

Many medical and psychosocial problems, both immediate and long term, cause the care of DS children become complex. An early intervention program is needed, namely, systematic program that includes therapy either surgery or correction or conservative structured by experts for comorbid, exercises, and activities designed to treat the developmental delays and minimize the negative impact of delays experienced by children with DS or other disabilities. Early intervention programs are generally multidisciplinary, consisting of speech and language therapy, physical therapy, and occupational therapy [10]. Health management, home environment, education, and vocational training greatly affect the functioning of DS children and assist their transition into adulthood. Family, friends, and community help are needed to support the mental development of DS children. Good cooperation from various parties and multidisciplinary approach is needed to achieve good health, growth and development conditions in children with DS [5], [10].

Sanglah Hospital as referral and teaching hospital needs to prepare facilities and infrastructure including sufficient human resources to provide comprehensive services to DS patients. Supporting data regarding the relationship between comorbidities and DQ in DS patients are needed as reference in planning service. These data are not yet available therefore researchers are interested in conducting this research.

\section{Materials and Methods}

This study was observational analytic study with cross-sectional approach, conducted on DS children who were treated in Sanglah Hospital in 2018. The data were obtained from medical record. The samples are those who meet the inclusion criteria and exclusion criteria. Inclusion criteria were age 0-18 years and suffering from DS. The sample will be excluded if the data are incomplete. The sample was selected by consecutive sampling, with the sample size calculated according to the estimated proportion of DS with single comorbidities of $10 \%$ [8], the difference in the expected proportions was $20 \%$, power was $80 \%$, and significance was $95 \%$. Calculation of the sample size using unpaired category formula obtained minimum sample size 30 subjects.

This research has been approved by ethics committee of the Faculty ofMedicine, UdayanaUniversity, with ethical clearance number 2019.02.1.0107. The data of this study include data on the characteristics and prevalence of children with DS and the analysis of the relationship between comorbidities and $D Q$ in DS children. The basic data included age, gender, education of father and mother, income of parents, and number of siblings. Characteristics of children with DS are described based on their congenital abnormalities, nutritional status; meanwhile, child's cognitive was assessed based on CAT-CLAMS.

All data were collected and processed using computer program. Categorical variables are described in number $(n)$ and prevalence in percentage (\%). The processed data are presented in the form of tables and narratives. Bivariate analysis using Chi-square was conducted to determine the relationship between comorbidities and DQ in DS children.

\section{Results}

There were 32 children with DS who were treated at Sanglah Hospital in 2018. The median age of the subjects was 2 years (range 1-12 years). The characteristics of the research subjects were divided into gender, parental education, parental age, and nutritional status (Table 1).

Table 1: Characteristics of subjects

\begin{tabular}{|c|c|c|c|}
\hline Characteristics & Total (\%) & Single comorbid & Multiple comorbid \\
\hline Age (year), median & $2(1-12)$ & & \\
\hline \multicolumn{4}{|l|}{ Gender, (n \%) } \\
\hline Male & $9(28.1)$ & $4(44.4)$ & $5(55.6)$ \\
\hline Female & $23(71.9)$ & $7(30)$ & $16(70)$ \\
\hline \multicolumn{4}{|c|}{ Father educational degree } \\
\hline Elementary school & $1(3.1)$ & $0(0)$ & $1(100)$ \\
\hline Junior high school & $6(18.8)$ & $3(50)$ & $3(50)$ \\
\hline Senior high school & $17(53.1)$ & $5(29)$ & $12(71)$ \\
\hline Diploma & $4(12.5)$ & $2(50)$ & $2(50)$ \\
\hline Bachelor & $4(12.5)$ & $1(25)$ & $3(75)$ \\
\hline \multicolumn{4}{|c|}{ Mother educational degree } \\
\hline Elementary school & $1(3.1)$ & $1(100)$ & $0(0)$ \\
\hline Junior high school & $7(21.9)$ & $3(43)$ & $4(57)$ \\
\hline Senior high school & $15(46.9)$ & $11(73)$ & $4(27)$ \\
\hline Diploma & $2(6.3)$ & $2(100)$ & $0(0)$ \\
\hline Bachelor & $7(21.9)$ & $4(57)$ & $3(43)$ \\
\hline \multicolumn{4}{|c|}{ Father's age (year), (n \%) } \\
\hline$<35$ & $5(15.6)$ & $3(60)$ & $2(40)$ \\
\hline$>35$ & $27(84.4)$ & $8(29)$ & $19(71)$ \\
\hline \multicolumn{4}{|c|}{ Mother's age (year), (n \%) } \\
\hline$<35$ & $16(50)$ & $8(50)$ & $8(50)$ \\
\hline$>35$ & $16(50)$ & $6(37.5)$ & $10(62.5)$ \\
\hline \multicolumn{4}{|l|}{ Nutritional status } \\
\hline Well nourish & $13(40.6)$ & $7(54)$ & $6(46)$ \\
\hline Malnutrition & $16(50)$ & $3(18)$ & $13(82)$ \\
\hline Severe malnutrition & $3(9.4)$ & $1(50)$ & $1(50)$ \\
\hline
\end{tabular}


Based on the type of comorbidity that children with DS have, 27 children (84.3\%) with endocrine disorders, 16 children (50\%) with congenital heart disease (CHD), 13 children (40.4\%) with other comorbid such as microcephaly, congenital cataract, palatoschizis, gastrointestinal defects, and congenital talipes equinovarus (CTEV). The most common endocrine disorders was congenital hypothyroidism $(81.25 \%)$, while the most common CHD was patent ductus arteriosus (PDA) (25\%) (Table 2).

Table 2: Types of comorbidities in DS children

\begin{tabular}{ll}
\hline Variables & $\mathbf{n = 3 2}$ \\
\hline Microcephaly, $\mathrm{n}, \%$ & $2(6.25)$ \\
Congenital cataract, $\mathrm{n}, \%$ & $2(6.25)$ \\
Palatoschizis, $\mathrm{n}, \%$ & $1(3.1)$ \\
Gastrointestinal, defect $\mathrm{n}, \%$ & $3(9.3)$ \\
Atresia ani & $1(3.1)$ \\
Hirschsprung & $1(3.1)$ \\
Hernia umbilicalis & $1(3.1)$ \\
CHD, $\mathrm{n}, \%$ & $16(50)$ \\
Complete atrioventricular septal defect (CAVSD) & $2(6.25)$ \\
PDA & $8(25)$ \\
Atrial septal defect (ASD) & $2(6.25)$ \\
Ventricular septal defect (VSD) & $4(12.5)$ \\
Endocrine disorders, $\mathrm{n}, \%$ & $27(84.37)$ \\
Congenital hypothyroidism & $26(81.25)$ \\
Micropenis & $1(3.1)$ \\
CTEV, $\mathrm{n}, \%$ & $2(6.25)$ \\
\hline CTEV: Congenital talipes equinovarus, PDA: Patent ductus arteriosus, CHD: Congenital heart disease.
\end{tabular}

Screening for the possibility of developmental delays in children with DS can be carried out with several tools, including Denver II and CAT-CLAMS. In this study, we used CAT-CLAMS and the result was dominated by "suspect" category.

Table 3: CAT-CLAMS scores of children with DS

\begin{tabular}{ll}
\hline Variables & $\mathrm{n}=32$ \\
\hline Suspect, $\mathrm{n}, \%$ & $21(65.6)$ \\
Mental retardation, $\mathrm{n}, \%$ & $6(18.8)$ \\
Communication disorder, $\mathrm{n}, \%$ & $5(15.6)$ \\
\hline
\end{tabular}

The description of $D Q$ score category for children with DS is shown in Table 3 . There were 21 children $(65.6 \%)$ with suspected, 6 children $(18.8 \%)$ with mental retardation, and 5 children (15.6\%).

Table 4: The association of comorbid with DQ in DS children

\begin{tabular}{llllll}
\hline Variables & \multicolumn{2}{l}{ Category DQ } & PR & Cl 95\% & p-value \\
\cline { 2 - 3 } & Disorder & Suspect & & & \\
\hline Comorbidity, n \% & $21(65.6)$ & $0(0)$ & 1.4 & $0.95-1.97$ & 0.033 \\
$\begin{array}{l}\text { Multiple } \\
\text { Single }\end{array}$ & $8(25)$ & $3(9.4)$ & & & \\
\hline
\end{tabular}

Bivariate Chi-square analysis of the association between comorbid and DQ is shown in Table 4. Multiple comorbidities were associated with $\mathrm{DQ}$ scores of children with DS. The relationship was statistically significant $(P R=1.4[95 \% \mathrm{Cl} 0.95-1.97], p=0.03)$.

\section{Discussion}

This study showed that most of the DS subjects were female, from parents graduated from senior high school. Many theories suggest that possible identified risk factor for the birth of baby with DS is parenteral age as the most common. Older maternal age plays an important role in DS births. Approximately $2 \%$ of recognized pregnancies in women under 25 years of age was trisomy, which increase to $10 \%$ in women above 36 years and to $33 \%$ in age 42 [11], [12].

This result is similar with Podder et al. [13] who stated that several studies have reported positive relationship between parity and DS but their results found that the probability of having baby with DS is more influenced by genetic age. The increase in age of all groups showed telomere loss, but the loss was greatest in the group of mothers in meiosis II and the smallest in the group of euploid mothers and the mother group of meiosis I in the middle. In addition, Sotonica et al. [14] found that 44 cases (34.6\% of DS children) had younger mothers, who were $<30$ years of age. The possible explanation of younger mothers who have children with DS is the consumption of alcohol, tobacco, environmental toxins, and drugs which cause chromosomes without disjunction. Young mothers tend to be sleep deprived, have unbalanced diet so as not to gain weight and accidental pregnancies which all lead to bad pregnancy habits. Our study found that the frequency of maternal age was balanced at age $<35$ years and $>35$ years.

Another study also discussed the role of paternal age in the birth of babies with DS. Research from Sotonica et al. [14] showed that paternal age also makes a difference when calculating the probability of genetic disorders. The highest percentage of DS children was in the group of fathers aged 30 and over and older than 40 (44.9\% and $32.3 \%$ ), respectively. Younger fathers $(22.8 \%$ of cases) having children with DS may have the same reasons when talking about young mothers, and are more likely that younger men whom have older partner may also contribute to the high prevalence of DS. Older men produce more sperm with aneuploidy. Our study found that $84.3 \%$ (27 of 32 subjects) had a paternal age of $>35$ years.

DS is a combination of dysmorphic facial features (which facilitates the diagnosis) and several associated visceral anomalies [15], [16]. Poaty et al. [17] found that mortality in DS remained high and was frequently associated with visceral malformations. Research by Unachak et al. [18] showed that $37.9 \%$ of DS patients suffered hypothyroidism, thus hypothyroidism is the most common thyroid disorder in DS. King et al. [19] also conducted study on the thyroid in 148 patients with DS and the results showed that $53 \%$ had hypothyroidism and stated that children with DS had higher risk of thyroid dysfunction than normal children. This study found that endocrine disorders were the most common comorbidities especially congenital hypothyroidism.

$\mathrm{CHD}$ is considered to be the most important clinical phenomenon of DS that contributes to morbidity and mortality in affected infants [20], [21]. The risk of CHD in DS is well known, but the type and frequency 
of the various categories of $\mathrm{CHD}$ are debated and are expected to cooccur with other congenital anomalies among children with DS [22]. The study in Atlanta by Forsey et al. [23] found that the most common CHD in DS was PDA. This study suggests that several factors such as ethnicity and geographic differences contribute to increase the frequency of PDA as they are associated with lower oxygen partial pressures [23], [24]. In this study, PDA was found as the most common type of $\mathrm{CHD}$ in DS.

Global developmental delay is predicted occur in children with DS, which affects motor, cognitive, language, and personal skills [25], [26]. This is in accordance with research in Aoki et al. [26] which showed that the speed of development of children with DS was found to be slower than that of children with DS. This delay is associated with the large number of comorbidities present in children with DS [26]. Vadakedom et al. [25] in their study found that most of the samples were globally delayed with hypotonic conditions. Delays in motor area in children with DS are predictable related to hypotonia conditions that occur in children with DS, including primitive reflexes and joint hypermobility that affect the ability to control posture so that they play role in movement and motor coordination.

Caput Scale/CAT-CLAMS as screening instrument for developmental disorders can be used to assess the level of cognitive development of children through the DQ score which will describe the proportion of development in the child. Global developmental delays are predicted occur in children with DS, which affect motor, cognitive, language, and personal skills. This delay is often associated with comorbidities found in DS children. This study proves that there is a comorbid relationship with $D Q$ in $D S$ children. Chi-squared analysis showed significant association between multiple comorbidities and $D Q$ in children with DS. The results of this study are in accordance with the results of research in Japan by Aoki et al. [26] which showed that the speed of development of children with DS was slower than their peers who were not primary school. This delay is associated with the large number of comorbidities that exist in children with DS [27], [28]. The results of this study are also reinforced by Kim et al. [27], 2016, who said that children with DS have several comorbidities and require surgical intervention as early as possible which is needed to reduce the negative effects on motor development and cognitive development [27]. The limitation of this study is that the investigators did not evaluate the process of administering developmental stimulation to patients with DS.

\section{Conclusion}

This study proved that there is an association between comorbidities and $\mathrm{DQ}$ in $\mathrm{DS}$ children. However, this study lacks of data specifications and completeness because it was highly dependent on retrospective medical record data. Further prospective studies are needed to obtain better results.

\section{References}

1. Bull MJ, Committee on Genetics. Clinical report health supervision for children with down syndrome. Pediatrics. 2011;128(2):392-406. http://doi.org/10.1542/peds.2011-1605 PMid:21788214

2. Committee on Genetics American Academy of Pediatrics Health supervision for children with Down syndrome. Pediatrics. 2001;107(2):442-9. http://doi.org/10.1542/peds.107.2.442 PMid:11158488

3. Lee B. Down Syndrome and other abnormalities of chromosome number. Dalam: Kliegman RM, Stanton BF, St Geme III JW Schor NF, editor. Nelson Textbook of Pediatrics. $20^{\text {th }}$ ed. Philadelphia, PA: Elsevier; 2016. p. 610-20.

4. Kawanto $\mathrm{FH}$, Soedjatmiko. Monitoring of Growth and Development in Children with Down Syndrome. Sari Pediatri. 2007;9:185-90

5. Malino Y, Soetjiningsih. Sindrom Down. In: Soetjiningsih Gde Ranuh IG, editor. Tumbuh Kembang Anak. $2^{\text {nd }}$ ed. Jakarta: Penerbit Buku Kedokteran EGC; 1995. p. 490-506.

6. Caban-Holt A, Head E, Schmitt F. Down syndrome. In Rosenberg's Molecular and Genetic Basis of Neurological and Psychiatric Disease. Ch. 15. Philadelphia: Elsevier; 2015. p. 163-70.

7. Myrelid A, Gustafsson, Ollars B, Anneren G. Growth charts for down's syndrome from birth to 18 years of age. Arch Dis Child. 2002;87(2):97-103. http://doi.org/10.1136/adc.87.2.97 PMid:12138052

8. Sularyo TS, Kadim M. Retardasi mental. Sari Pediatr 2000;2:170-7.

9. Dhamayanti M, Herlina M. Skrining gangguan kognitif dan bahasa menggunakan caput scale. (Cognitive adaptive test/ clinical linguistic and auditory milestone scale-cat/clams). Sari Pediatr. 2009;11(3):189-98.

10. O'Keefe L. Caring for Children with Down syndrome. AAP News; 2002. p. 290.

11. Wajuihian SO. Down syndrome: An overview. Afr Vision Eye Health. 2016;75(1):a346.

12. Shalaby HM. A study of new potential risk factors for Down syndrome in Upper Egypt. Egypt J Med Hum Genet 2011;12(1):15-9. https://doi.org/10.1016/j.ejmhg.2011.02.009

13. Podder G, Banerjee J, Madhusnata. Paternal age combined with maternal age influences the incidence of down syndrome. Int J Pharmacol Clin Res. 2014;6:186-8.

14. Sotonica M, Mackic-Djurovic M, Hasic S, Kiseljakovic E, Jadric R, Ibrulj S. Association of parental age and the type of down syndrome on the territory of Bosnia and Herzegovina. Med Arch 2016;70:88-91. 
15. Alao MJ, Adjagba PM, Yekpe P. Congenital visceral malformations in children with Down syndrome followed in the pediatric unit of the CNHU, Cotonou, Benin. J Down Syndr Chr Abnorm. 2017;3:1-3. http://doi.org/10.4172/2472-1115.1000121

16. Stoll C, Dott B, Alembik Y, Roth MP. Associated congenital anomalies among case with Down syndrome. Eur J Med Genet. 2015;58(12):674-80.

PMid:26578241

17. Poaty $H$, Niama AC, Voumbo MY. Prevalence and pattern of associated anomalies in preliminary working among Congolese children with Down syndrome: Analysis of 83 patients and African review. J Genet Disord. 2018;2:1-5.

18. Unachak K, Tanpaiboon $P$, Pongprot $Y$, Sittivangkul $R$, Silvilairat S, Dejkhamron P, Sudasna J. Thyroid functions in children with Down's syndrome. J Med Assoc Thai. 2008;91(1):56-61. PMid:18386545

19. King K, O'Gorman CS, Gallagher S. An audit of the management of thyroid disease in children with Down syndrome. Ir Med J. 2014;107(4):118-9. PMid:24834588

20. Jalili Z, Jalili S. Congenital heart disease in children with Down syndrome in Kermanshah, West of Iran during 2002-2016. Int J Pediatr. 2017;5:6095-102.

21. Elmagrpy Z, Rayani A, Shah A, Habas E, Aburawi E. Down syndrome and congenital heart disease: Why the regional differences as observed in the Libyan experience? CVJ Afr. 2011;22:306-9.

22. Benhaourech S, Drighil A, Hammiri AE. Congenital heart disease and Down syndrome: Various aspect of confirmed association. CVJ Afr. 2016;27(5):287-90. http://doi.org/10.5830/ CVJA-2016-019

PMid:27805241

23. Forsey JT, Elmasry OA, Martin RP. Patent arterial duct. Orphanet J Rare Dis. 2009;4(1):17. http://doi.org/10.1186/1750-1172-4-17 PMid:19591690

24. Abbag FI. Congenital heart diseases and other major anomalies in patients with Down syndrome. Saudi Med J. 2006;27(2):219-22.

PMid:16501680

25. Vadakedom SS, Krishnan DK, Mammen DS, Bindhu KP, Antony JM. Medical problems in children with Down syndrome. Int J Adv Med. 2018;5:1290-94.

26. Aoki S, Yamauchi Y, Hashimoto K. Developmental trend of children with Down's syndrome -How do sex and neonatal conditions influence their developmental patterns? Brain Dev Jpn. 2018;40:181-7.

27. Kim HI, Kim SW, Kim J, Jeon HR, Jung DW. Motor and cognitive developmental profile in children with Down syndrome. Ann Rehabil Med. 2017;41(1):97-103. http://doi.org/10.5535/ arm.2017.41.1.97

PMid:28289641

28. Wasant $\mathrm{P}$, Boonyawat $\mathrm{B}$, Tritilanunt $\mathrm{S}$, Vatanavicharn $\mathrm{N}$, Sathienkijakanchai A, Ratanarak $\mathrm{P}$, et al. Factors influencing development of Down syndrome children in the first three years of life: Siriraj experience. J Med Assoc Thai. 2008;91(7):1030-7. PMid:18839841 